\title{
MICROFACIES AND MICROFOSSILS IN UPPER JURASSIC LIMESTONES FROM CHEILE TURENILOR
}

\author{
EMANOIL SĂSĂRAN ${ }^{1}$, IOAN I. BUCUR ${ }^{1}$, IOANA PRICA ${ }^{1}$
}

\begin{abstract}
In the Cheile Turenilor (Tureni Gorges) area, a carbonate succession about $150 \mathrm{~m}$ thick developed on top of island arc magmatites. It mainly consist of gravity - induced deposits (debris flows, mass flows and grain flows). Coral, sponges and stromatoporoid bioconstructions are associated. Microbolites play an important role, as binders of the intraclastic rudstones/ grainstones facies, as well as of the incorporated corals, sponges, stromatoporoids, bryozoans, molluscs.
\end{abstract}

KEY WORDS: limestone, facies, microfacies, microfossils, Late Jurassic, Trascău, Apuseni Mountains.

\section{INTRODUCTION}

Cheile Turenilor is located in the north-eastern part of Trascău Mountains, between Tureni and Copăceni (Fig. 1). The succession of Mesozoic deposits in the area belongs to the northern end of Bedeleu Nappe, which is included within the Austrian Transilvanides (Balintoni \& lancu, 1986; Balintoni, 1997). The original area from where Bedeleu Nappe orginated was an island arc (Nicolea et al., 1992; Gandrabura, 1981; Cioflică \& Nicolae, 1981; Nicolae, 1994; Cioflică et al., 1981; Balintoni, 1997, etc.), below which subduction took place. These island arc deposits occur as a north-south elongated strip below Tertiary formations in the the SănduleştiBuru-Poiana Aiudului areas, as well as in Cheile Turenilor. On the top of the arc magmatites, Stramberk-type limestone formed. Hauer \& Stache (1863) described coral fragments and Sphaerodus teeth in these deposits for the first time, and attributed them to the Late Jurassic (Tithonian) based on the similarities with other Stramberk-type limestones. The carbonate deposits in the region are part of the Sănduleşti Formation (Dragastan et al., 1987).

\section{FACIES, MICROFACIES AND MICROFOSSILS}

In the area studied, on the top of the island arc-type magmatites (breccias, agglomerates, rhyolitic tuffs interlayered with lava flows) the carbonate succession is about $150 \mathrm{~m}$ thick. It is mainly represented by deposits of gravity - induced processes. Intraclastic-bioclastic rudstones are the facies that dominate the whole succession cropping out in Cheile Turenilor.

1 "Babeş-Bolyai" University, Department of Geology. Str. Kogălniceanu 1, RO-3400 Cluj-Napoca, Romania.E-mail: esasaran@bioge.ubbcluj.ro; ibucur@bioge.ubbcluj.ro; pioana@bioge.ubbcluj.ro. 


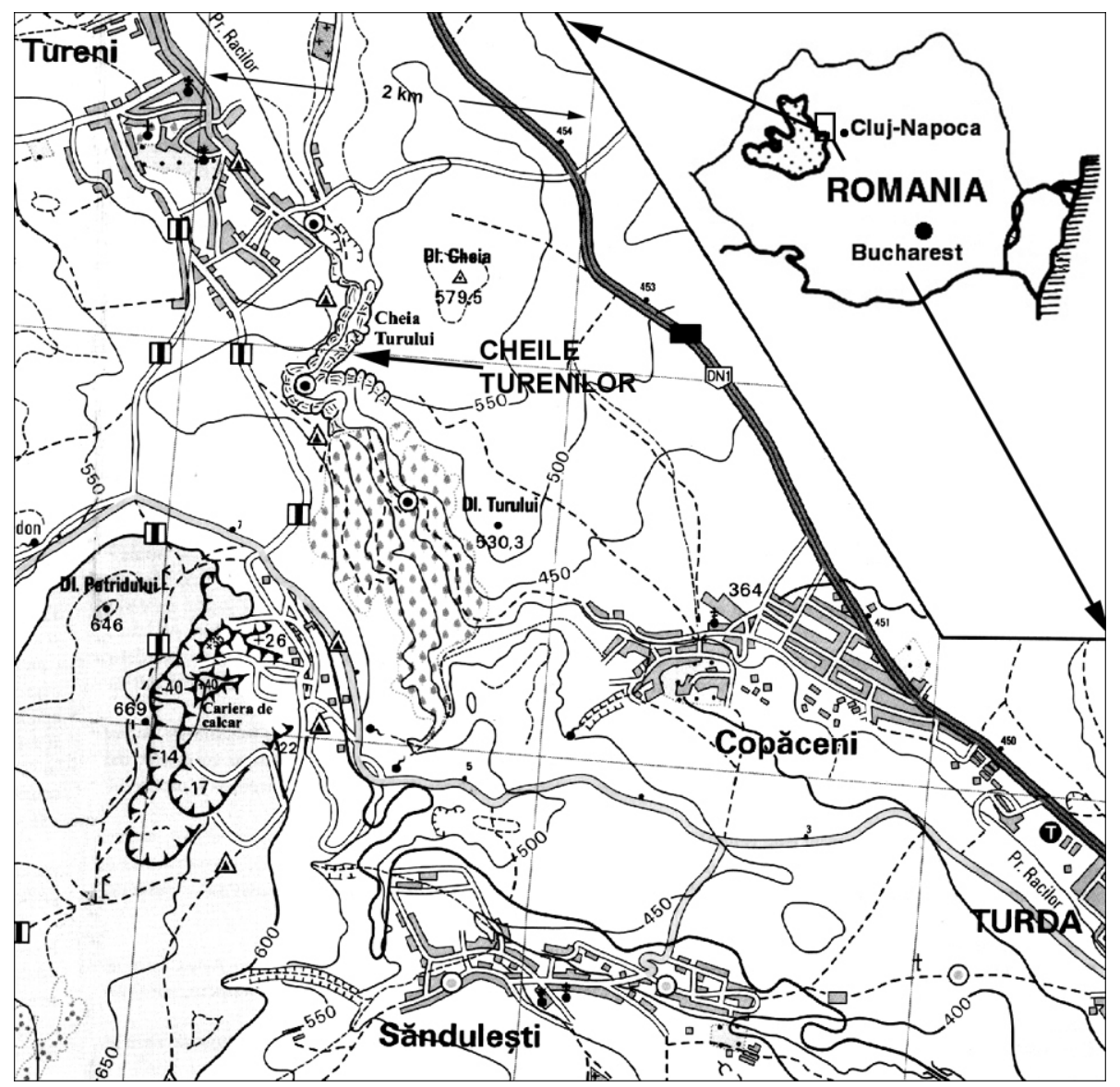

Figure 1 - Location of the study area

\subsection{Debrites and conglomeratic deposits}

Description: On the top of the island arc complex, the succession commences with layers of breccia and conglomerates containing blocks of "reef" limestone surrounded by a red matrix (PI. I). They show a lens-type geometry, a reduced lateral continuity - meters or tens of meters, and decimetric-centimetric thickness. The blocks are arranged chaotically, no sorting is evident, while the clasts of various size are rounded to angular. The matrix is a mixture of finegrained carbonate (including silt- and sand sized particles), lithoclasts of island arc magmatic rocks, quartz, and fresh feldspar, as well as terrigenous mud, rich in iron and manganese oxides. The matrix of the conglomeratic deposits is represented by extraclastic-ooidic grainstones (PI I, fig. 3; PI III, fig. 1). The nuclei of the ooids are generally large, and consist of fragments of volcanic rocks and quartz. The cortices are very thin. 
Szentpétery (1904) attributed a Triassic age to these deposits. Study of the carbonate pebbles reveals the following microfacies:

- coral boundstones with sponges, stromatoporoids (PI. IV, fig. 2,3), and halimedaceans (Nipponophycus ramosus YABE \& TOYAMA) (PI. VIII, fig.1, 3). The internal sediment is represented by bioclastic grainstones/packestones, with Terquemella sp., (PI. VIII, fig.2), Thaumatoporella parvovesiculifera RAINERI, Lithocodium aggregatum ELLIOTT, Mohlerina basiliensis (MOHLER) (PI.X, fig. 5), Andersenolina sp., "Tubiphytes" morronensis CRESCENTI, fragments of echinoderms, molluscs, miliolids, and bryozoans.

- bioclastic peloidal grainstones/packestones with Salpingoporella enayi BERNIER (PI. VII, fig. 5), Clypeina sulcata (ALTH) (PI. VII, fig. 6), Diversocalis sp. (PI. VIII, fig. 6), Radiomura cautica SENOWBARI - DARYAN \& SCHAEFFER, Protopeneroplis striata WEYNSCHENK (PI. IX, fig. 5), Trocholina sp., "Tubiphytes" morronensis CRESCENTI, Mercierella dacica DRAGASTAN (PI. X, fig 1), fragments of corals, echinoderms, and miliolids.

Interpretation: Unsorted blocks of "reef" carbonate rocks in a chaotic arrangement, and clasts of various size in a finer-grained a matrix are all arguments for considering these deposits as debris flows, or mass flows (Coniglio \& Dix, 1992; Stow, 1995; Einsele, 1991; Enos \& Moore, 1983). The microfossils identified within the limestone pebbles do not allow exact estimation of their age, but indicate the Late Jurassic.

\subsection{Grain flow deposits}

Description: On the top of the debrites and conglomeratic deposits, wellsorted banks of carbonate sand bodies develop, showing normal and inverse grading (PI III, fig.3), interlayered with hemipelagic limestones with small-sized belemnites and ammonites. The carbonate sands have sheet-type geometries, with erosive basal contact (PI. II,PI. III, fig. 3) and are intraclastic bioclastic rudstones/ grainstones. The latter contain Salpingoporella johnsoni (DRAGASTAN) (PI. VII, fig. 2), Salpingoporella annulata CAROZZI (PI. VII, fig. 3-4), Clypeina sulcata (ALTH), Neotrocholina sp. (PI. IX, fig. 4), Andersenolina sp., Lenticulina sp., Nautiloculina sp. (PI. IX, fig. 6), Neokilianina rahonensis (FONRY \& VINCENT) (PI. IX, fig. 2), Charentia sp. (PI. IX, fig. 3), Mercierella dacica DRAGASTAN, "Tubiphytes" morronensis CRESCENTI, fragments of corals, bryozoans, sponges, and echinoderms. Towards the top of these banks ooids occur, while the frequency of carbonate sand bodies increases while the hemipelagic limestones decrease.

The hemipelagic limestones are represented by bioclastic wackestone/ packestone with sponge spicules, frequent echinoderms plates, small belemnites, ammonites and hemipelagic foraminifers (Lenticulina sp.).

Interpretation: The well-sorted, normal and inversely graded sheet-type carbonate sand bodies with erosive basal contacts, interlayered with hemipelagic limestones, indicate grain flow deposits (Lowe, 1982; Einsele, 1991; Stow et al., 1996). 


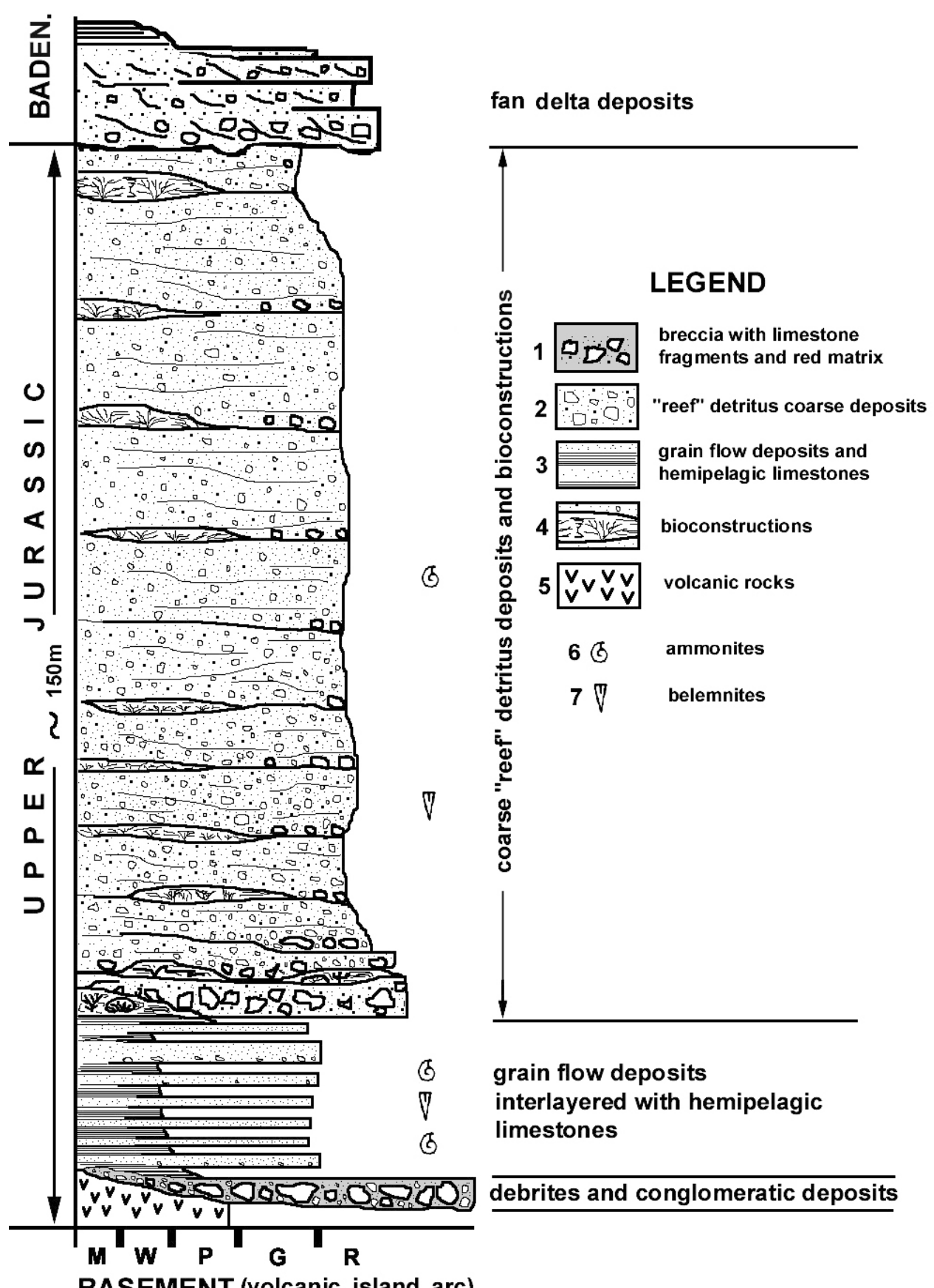

BASEMENT (volcanic island arc)

Figure 2 - Sedimentological log through the limestones in Cheile Turenilor area. 


\subsection{Coarse "reef" detritus deposits and bioconstructions}

Description: A succession of carbonate breccia about $120 \mathrm{~m}$ thick occurs above the grain flow deposits. It consists of sheets containing cobbles of "reef" limestone in a fine-grained carbonate matrix (including silt- and sand sized particles) (PI. IV, fig.1). These deposits are poorly sorted, they lack statification, and the clasts are chaotically displayed. (PI. IV, fig.1). The clasts are angular to subrounded, and vary in size from pebbles-to cobbles. They mainly consist of boundstones with corals and sponges, coralligenous-thrombolitic boundstones, and bioclastic grainstones/packestones. Both in the matrix, and in the clasts, the following microfossils were identified: Salpingoporella pygmaea (GÜMBEL) (PI. VII, fig. 1), Salpingoporella annulata CAROZZI, Clypeina sulcata (ALTH), Trocholina sp., Andersenolina sp, Protopeneroplis sp., Nautiloculina oolitica MOHLER, "Tubiphytes" morronensis CRESCENTI, Mohlerina basiliensis (MOHLER), Radiomura cautica SENOWBARI - DARYAN \& SCHAEFFER, Mercierella dacica DRAGASTAN, sponges, coral fragments, mollusks, echinoderms, bryozoans, and rare small belemnites, and ammonites. The corals and the sponges are intensely encrusted. The most frequent identifiable encrusting microfossils are Lithocodium aggregatum ELLIOTT (PI. III, fig. 5; PI. VI, fig. 1-3,6), Thaumatoporella parvovesiculifera RAINERI (PI. VI, fig.4-5), Koskinobullina socialis CHERCHI \& SCHROEDER (PI. VI, fig. 2-3), Radiomura cautica SENOWBARI - DARYAN \& SCHAEFFER (PI. VIII, fig. 5), Trogrotella incrustans WERNLI \& FOOKES (PI. VI, fig. 6), Bacinella irregularis RADOIČIC, and encrusting foraminifers (PI. VI, fig. 1).

The bases part of the breccia beds are usually erosional, while the upper parts are finely graded. The tops of these breccia beds are intensely encrusted by microbolites, sometimes accompanied by coral bioconstructions with sponges and stromatoporoids. These bioconstructions are not proper reef-builders, but sometimes they show a constratal growth fabric (sensu Insalaco, 1998). The bioconstructions are intensely encrusted by microbial structures, algae, and foraminifera. The microbolites incorporated corals, sponges, and stromatoporoids, and at the same time they stabilized (bound) the intraclastic rudstones/grainstones. According to the classification of Riding (1991,2000), and Schmid (1996), the most frequent microbolite type identified in Cheile Turenilor is clotted mesostructure (thrombolite) (PI. V, fig. 1-2) represented by mesoclots with shapes varying from simple spheroids to polilobate masses. The mesoclots consist of diverse microstructures including peloids, grumelous fabric, and cement. The microbolites are frequently associated with encrusting algae and foraminifera. The internal sediment between the bioconstructions is in general represented by bioclastic packstone/ wackestone with Terebella sp. (PI. V, fig. 2), annelid tubes, Lenticulina sp., "Tubiphytes" morronensis CRESCENTI, sponge spicules, and echinoderm plates.

Interpretation: Poorly sorted deposits lacking stratification, containing angular to subrounded pebble-to cobble sized, chaotically arranged clasts in a finegrained matrix allow us to regard these deposits as gravity flows (Coniglio \& Dix, 1992; Stow, 1995; Einsele, 1991; Enos \& Moore, 1983).

The coral - microbial bioconstructions associated with gravity flow deposits contain sponge spicules, echinoderm plates, "Tubiphytes" morronensis, Terebella sp., annelid tubes, hemipelagic foraminifera (Lenticulina sp) indicating an open marine environment, below normal wave basis. The Terebella - "Tubiphytes" morronensis 
association is tolerant of disaerobic conditions and occupied a deep environment (Schmid, 1996).

\section{CONCLUSIONS}

In Cheile Turenilor area the carbonate succession is mainly represented by gravity-induced deposits (debris flows, grain flows, mass flows). In addition, hemipelagic limestones are present in the basal part of the succession, while in the middle and upper part coral bioconstructions with sponges and stromatoporoids are present, indicating an open marine environment below normal wave basis. The association of gravity flow deposits with hemipelagic limestones and bioconstructions are indicative of fore-"reef" slope environment.

\section{Acknowledgements}

We thank Robert Riding (Cardiff) for revewing the manuscript and improvement of the English text.

\section{REFERENCES}

Balintoni, I. (1997) - Geotectonica terenurilor metamorfice din România. Editura Carpatica, 176 p., Cluj-Napoca.

Balintoni, I., lancu, V. (1986) - Lithostratigraphic and tectonic units in the Trascău Mountains north of Mânăstirea Valley. D. S. Inst. Geol. Geofiz., vol. 70-71/5 (1983-1984), p. 4556, Bucureşti.

Cioflică, G., Nicolae, I. (1981) - The Origin, evolution and tectonic setting of the alpine ophiolites from the South Apuseni Mountains (Romania). Rev. Roum. Geol., Geophys., Geol., 25, p. 19-29, Ed. Acad. Rom., Bucureşti.

Cioflică, G., Savu, H., Nicolae, I., Lupu, M., Vlad, S. (1981) - Alpine ophiolitic complexes in South Carpathians and South Apuseni Mountains (Guide Exc. A3) - Carp.- Balk. Geol. Asso., XII Congr. Guidebook Ser., Inst. Geol. Geophys., 18, p.1-80, Bucureşti.

Coniglio, M., Dix, G.R. (1992) - Carbonate slope. In: Walker, R.G. \& James, N.P. (eds.), Facies models, response to sea level change. Geol. Assoc. Canada, p. 349-373.

Dragastan, O., Ciubotaru, T., Brustur, T. (1987) - Neoteutloporella socialis (Praturlon), algue "récifale" du domaine tethysien. Revue du Paleobiologie, 6/1, p.143-149, Genève.

Einsele, G., 1991 - Submarine mass flow deposits and turbidites. In: Einsele et al. (eds.) Cycles and events in stratigraphy. Springer- Verlag, p. 313-340, Berlin.

Enos, P., Moore, C. H. (1983) - Fore - reef slope environment, in Scholle, P. A., Bebout, D. G. \& Moore, C. H., (eds.), Carbonate depositional environments. AAPG, Memoir 33, p. $508-537$, Boulder.

Gandrabura, E. I. (1981) - Studiul mineralogic, petrografic şi geochimic al eruptivului mezozoic din Munții Trascău. Anuarul Inst. Geol. Geofiz., LVIII, p.5-122, Bucureşti.

Hauer, F., Stache, G. (1863) - Geologie Siebenbürgens, 637p., Wien.

Insalaco, E. (1998) - The descriptive nomenclature and classification of growth fabrics in fossil scleractinian reefs. Sedimentary Geology, 118, p. 159-186, Amsterdam.

Lowe, D. R. 1982 - Sediment gravity flows: depositional models with special reference to the deposits of high - density turbidity currents. J. sedim. Petrol., 52, p.279-297. 
MICROFACIES AND MICROFOSSILS IN THE UPPER JURASSIC LIMESTONES ...

Nicolae, I. (1994) - The ophiolitic rocks from Mureş Valley, ALCAPA II, Field Guide-Book, Rom. Jour. Tect. Reg. Geol., 75 Suppl. 2, 36-140, Bucureşti.

Nicolae, I., Soroiu, M., Bonhomme, M. G. (1992) - Ages K-Ar des Quelques ophiolites des Monts Apuseni de Sud, et leurs signification géologique (Roumanie), Geol. Alpine, 68, p.77-83, Grenoble.

Riding, R., 1991- Classification of microbial carbonates: in Riding, R. (ed): Calcareous algae and stromatolites: Springer-Verlag, p. 21-51, Berlin.

Riding, R., 2000 - Microbial carbonates: the geological record of calcified bacterial-algal mots and biofilms. Sedimentology, 47 (suppl. 1), p. 179-214, London.

Schmid, D., 1996 - Marine microbolites and micro-encrusters from the Upper Jurassic. Profil, 9, p. 101-251, Stuttgart.

Stow, D. A. V. (1995) - Deep clastic seas, in H. G. Reading (ed.): Sedimentary environments and facies. Blackwell Science, Second Ed., p. 399-444.

Stow, D. A. V., Reading, H. G., Collinson 1996 - Deep seas, in H. G. Reading (ed.): Sedimentary Environments: Processes, Facies and Stratigraphy. Blackwell Science, Third Ed., p. 395-453.

Szentpétery, Z. 1904 - Die Petrographischen Verhältnisse des Eruptivzuges Tur-Torokzkó. Orv. Term. Tud. Ert., XXIV, p.1-36, Budapest.

\section{PLATES}

Plate I - Debrites and conglomeratic deposits from the basal part of the succesion in Cheile Turenilor.

Fig. 1 - Breccia

Fig. 2,4 - Detail of the fig. 1.

Fig. 3 - Conglomerates

Plate II - Grain flow deposits

Fig. 1,2 - Carbonate sand bodis interlayered with hemipelagic limestones.

Fig. 3,4 - Well - sorted banks of carbonate sand bodies with angular to rounded clasts at their bases, grading upward into medium sand and fine grained limestones.

Plate III - Microfacies and microfossils from Sănduleşti Limestone Formation in Cheile Turenilor.

Fig. 1 - Extraclastic oolitic rudstone/grainstone. Scale bar is $2 \mathrm{~mm}$.

Fig. 2 - Bioclastic packstone (bottom) grading into a intraclastic-bioclastic grainstone/ rudstone (grain flow deposits with inverse grading). Scale bar is $5 \mathrm{~mm}$.

Fig. 3 - Small chanel with erosive basal contact. Bioclastic wackestone (bottom) and bioclastic grainstone towards top. Scale bar is $5 \mathrm{~mm}$.

Fig. 4 - Ooid sands (bottom) stabilized by microbolites. Scale bar is $2 \mathrm{~mm}$.

Fig. 5 - Coralligenous-thrombolitic boundstone. A - grumelous microstructure; B - coral; C - Lithocodium aggregatum ELLIOTT; D - sponge; E - microbial pseudostalactite structures. Scale bare is $1 \mathrm{~mm}$.

Plate IV - Microfacies and microfossils from Sănduleşti Limestone Formation in Cheile Turenilor.

Fig. 1 - Intraclastic bioclastic rudstones (coarse "reef" detritus deposits). Scale bar is $2 \mathrm{~cm}$.

Fig. 2 - Boundstones with corals and sponges. Scale bar is $1 \mathrm{~cm}$.

Fig. 3 - Sclerosponge. Scale bare is $5 \mathrm{~mm}$. 
Plate V - Thrombolitic facies from Sănduleşti Formation in Cheile Turenilor.

Fig. 1 - Mesoclots composed of grumelous microstructures. Scale bar is $5 \mathrm{~mm}$.

Fig. 2 - Coralligenous-thrombolitic boundstone. A - Terebella sp.; B - sponge; C peloidal microstructure; $\mathrm{D}$ - grumelous microstructure. Scale bar is $1 \mathrm{~mm}$.

Plate VI - Encrusting microfossils.

Fig. 1 - Encrusting foraminifers. Scale bar is $0.4 \mathrm{~mm}$

Fig. 2 -3 Lithocodium aggregatum ELLIOTT and Koskinobullina socialis CHERCHI \& SCHROEDER. Scale bars are $0.8 \mathrm{~mm}$ and $0.4 \mathrm{~mm}$, respectively.

Fig. 4 -5 Thaumatoporella parvovesiculifera RAINERI. Scale bars are $0.8 \mathrm{~mm}$ and $0.4 \mathrm{~mm}$, respectively.

Fig. 6 - Lithocodium aggregatum ELLIOTT and Trogrotella incrustans WERNLI \& FOOKES. Scale bar is $0.4 \mathrm{~mm}$.

Plate VII - Dasycladaleans from Sănduleşti Limestone Formation in Cheile Turenilor.

Fig. 1 - Salpingoporella pygmaea (GÜMBEL). Scale bare is $0.4 \mathrm{~mm}$.

Fig. 2 - Salpingoporella johnsoni (DRAGASTAN). Scale bare is $0.2 \mathrm{~mm}$.

Fig. 3,4 - Salpingoporella annulata CAROZZI. Scale bare is $0.4 \mathrm{~mm}$.

Fig. 5 - Salpingoporella enayi BERNIER. Scale bare is $0.4 \mathrm{~mm}$.

Fig. 6 - Clypeina sulcata (ALTH). Scale bare is $0.4 \mathrm{~mm}$.

Plate VIII - Dasycladaleans, halimedaceans, rivulariaceans from the Sănduleşti Limestone Formation in Cheile Turenilor.

Fig. 1, 3 - Nipponophycus ramosus YABE \& TOYAMA. Scale bars are $0.8 \mathrm{~mm}$ and $0.2 \mathrm{~mm}$, respectively.

Fig. 2 - Terquemella sp.. Scale bar is $0.2 \mathrm{~mm}$.

Fig. 4 - Lithocodium aggregatum ELLIOTT. Scale bar is $0.4 \mathrm{~mm}$.

Fig. 5 - Radiomura cautica SENOWBARI - DARYAN \& SCHAEFFER. Scale bar is $0.8 \mathrm{~mm}$.

Fig. 6 - Diversocalis sp.. Scale bar is $0.4 \mathrm{~mm}$.

Plate IX - Foraminifera from the Sănduleşti Limestone Formation in Cheile Turenilor.

Fig. 1 - Lenticulina sp.. Scale bar is $0.4 \mathrm{~mm}$.

Fig. 2 - Neokilianina rahonensis FONRY \& VINCENT. Scale bar is $0.4 \mathrm{~mm}$.

Fig. 3 - Charentia sp.. Scale bar is $0.2 \mathrm{~mm}$.

Fig. 4 - Neotrocholina sp.. Scale bar is $0.2 \mathrm{~mm}$.

Fig. 5 - Protopeneroplis striata WEYNSCHENK. Scale bar is $0.2 \mathrm{~mm}$.

Fig. 6 - Nautiloculina sp.. Scale bar is $0.2 \mathrm{~mm}$.

Plate $\mathbf{X}$ - Foraminifers and other microfossils from the Sănduleşti Limestone Formation in Cheile Turenilor.

Fig. 1 - Mercierella dacica DRAGASTAN. Scale bar is $0.2 \mathrm{~mm}$.

Fig. 2,3 - "Trocholina" sp. Scale bar is $0.4 \mathrm{~mm}$.

Fig. 4 - "Tubiphytes" morronensis CRESCENTI. Scale bar is $0.8 \mathrm{~mm}$.

Fig. 5 - Mohlerina basiliensis (MOHLER). Scale bar is $0.2 \mathrm{~mm}$.

Fig. 6 - Lithocodium aggregatum ELLIOTT and Trogrotella incrustans WERNLI \& FOOKES. Scale bar is $0.8 \mathrm{~mm}$. 
MICROFACIES AND MICROFOSSILS IN THE UPPER JURASSIC LIMESTONES ...

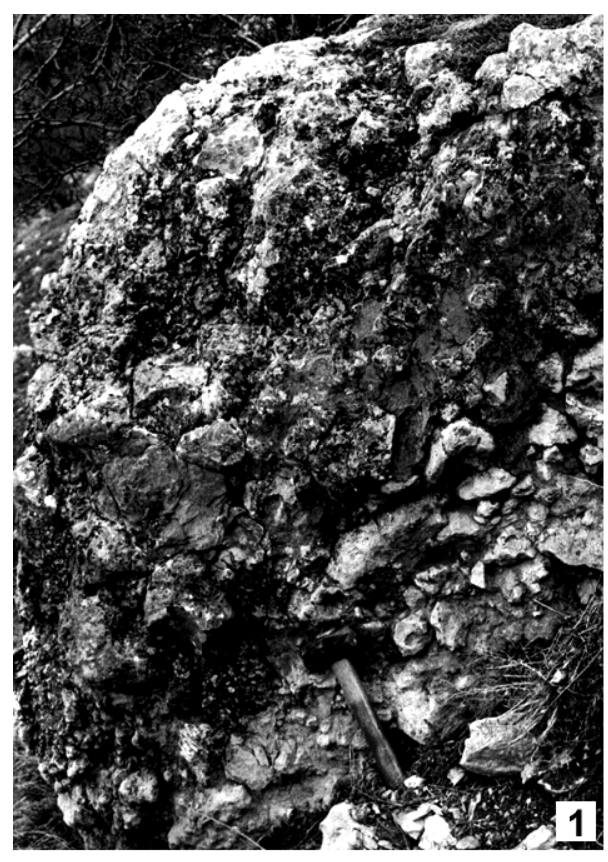

PLATE I
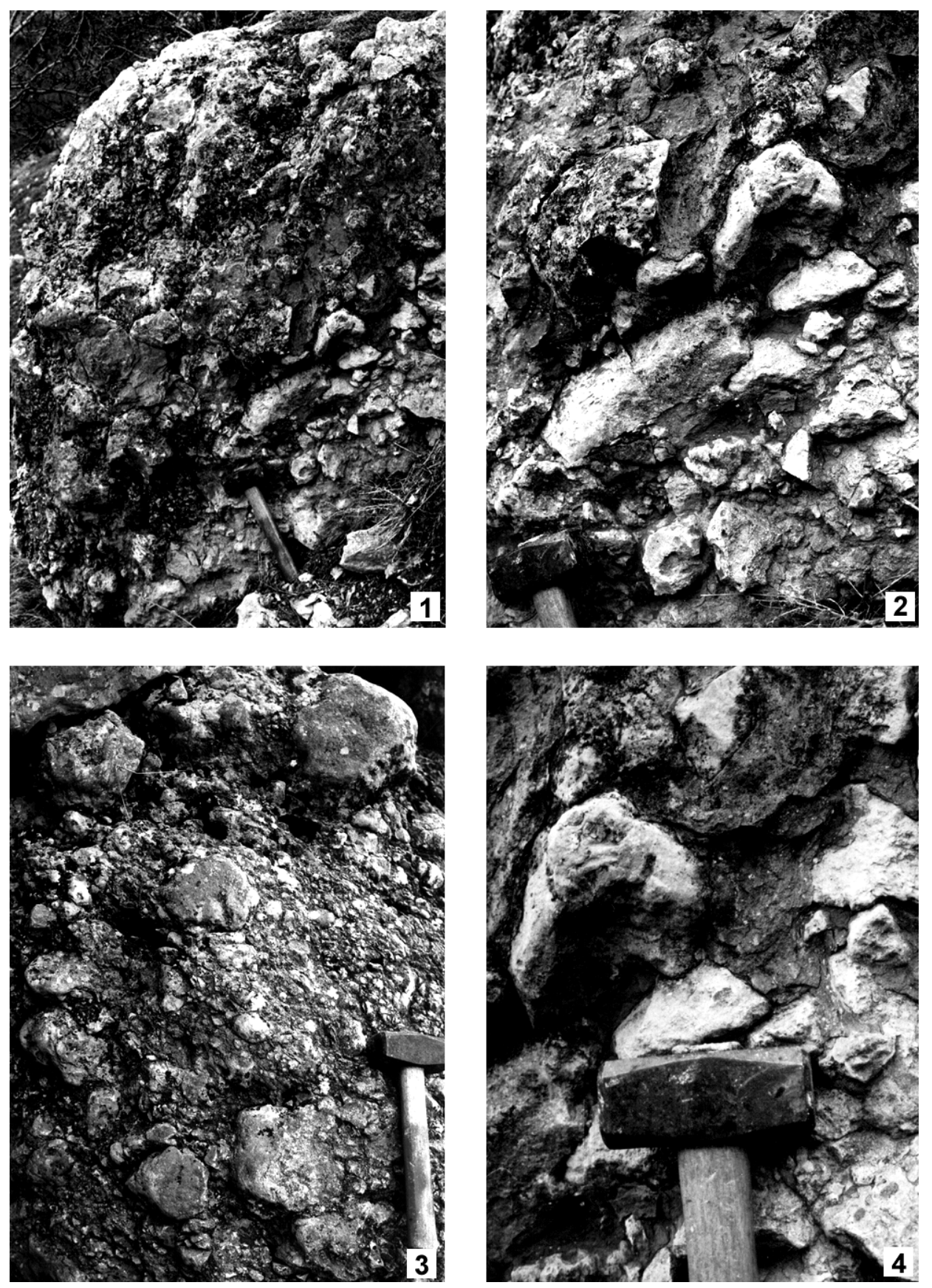
PLATE ॥
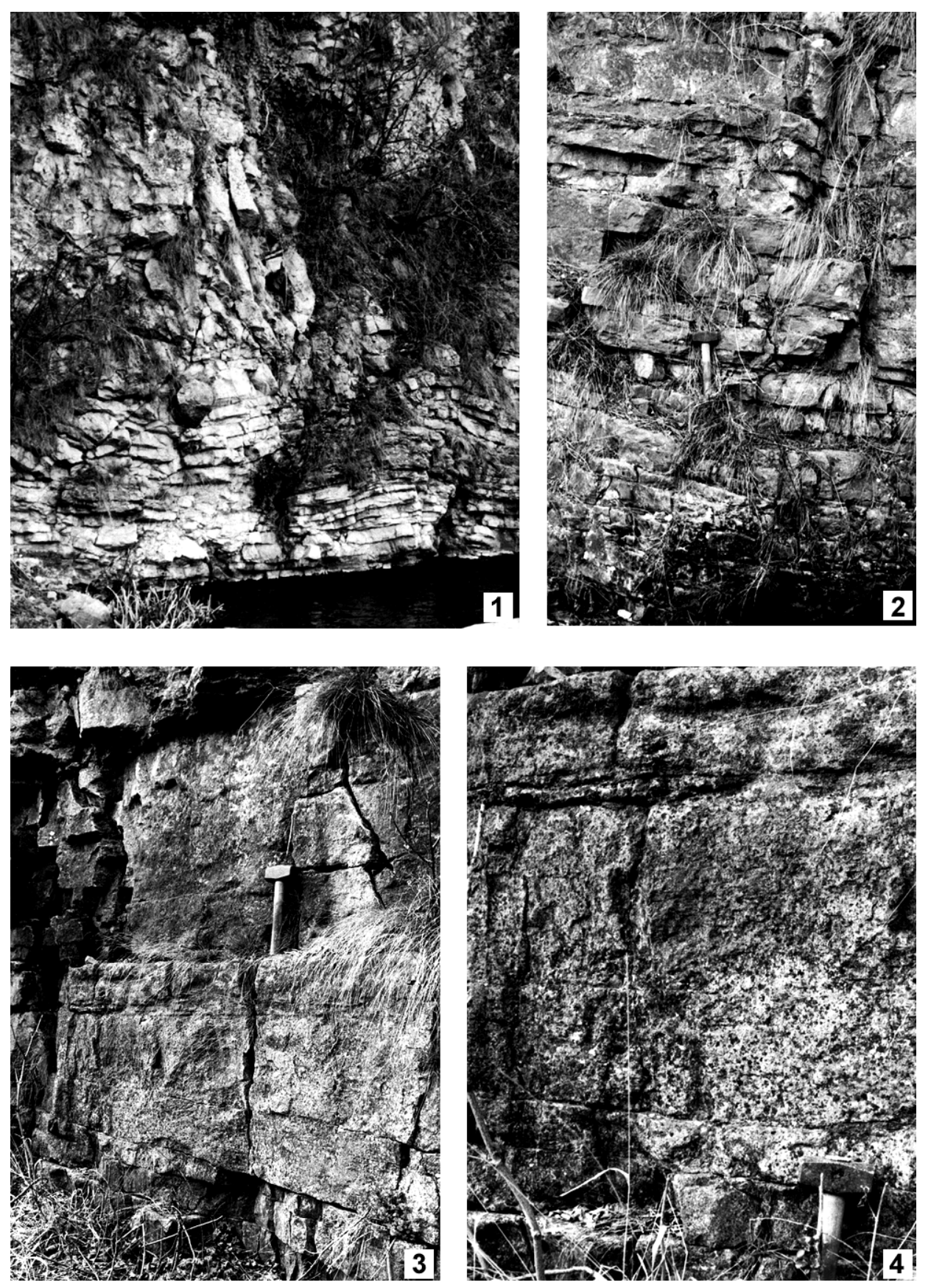
MICROFACIES AND MICROFOSSILS IN THE UPPER JURASSIC LIMESTONES ...

PLATE III
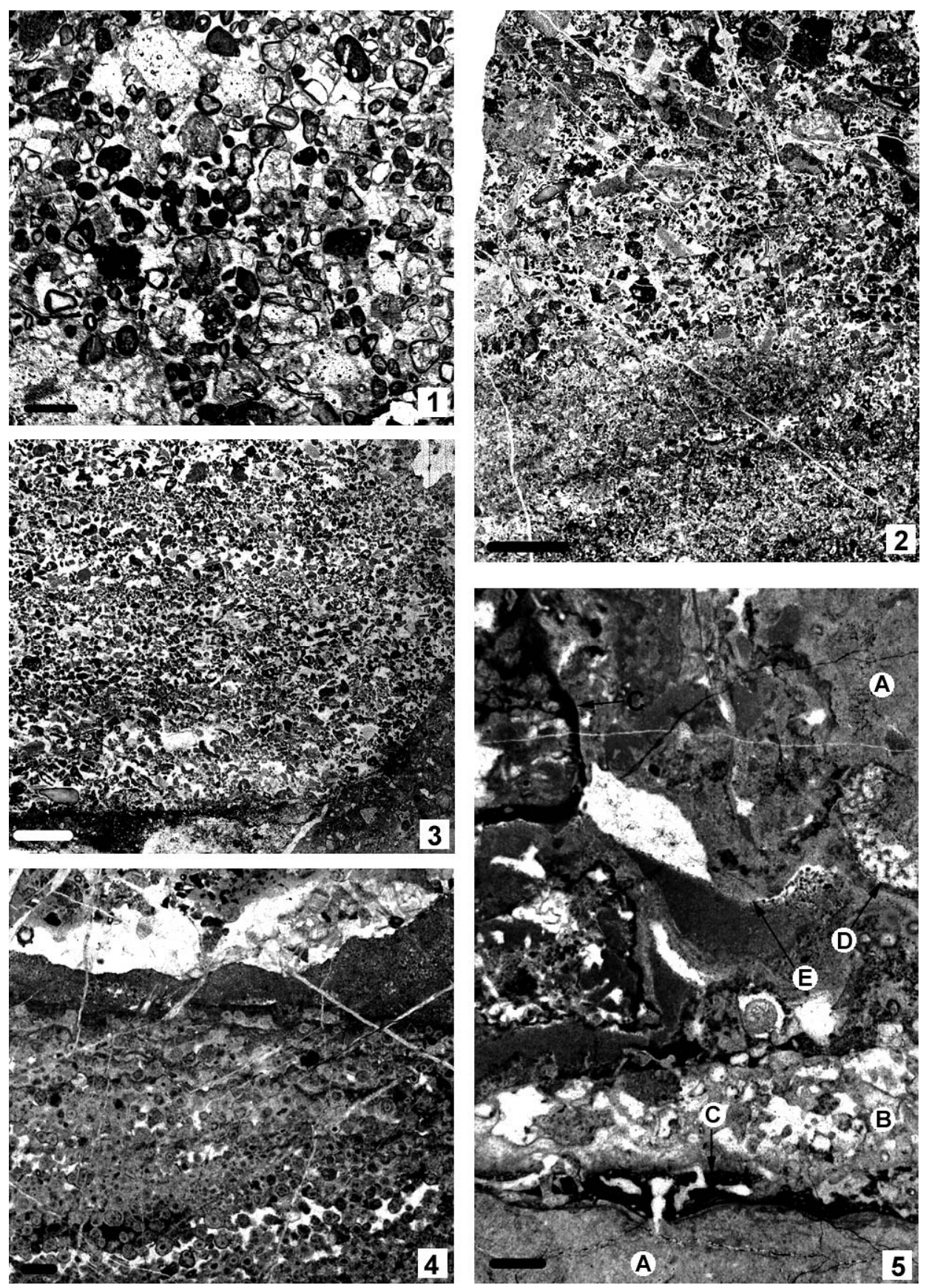
PLATE IV
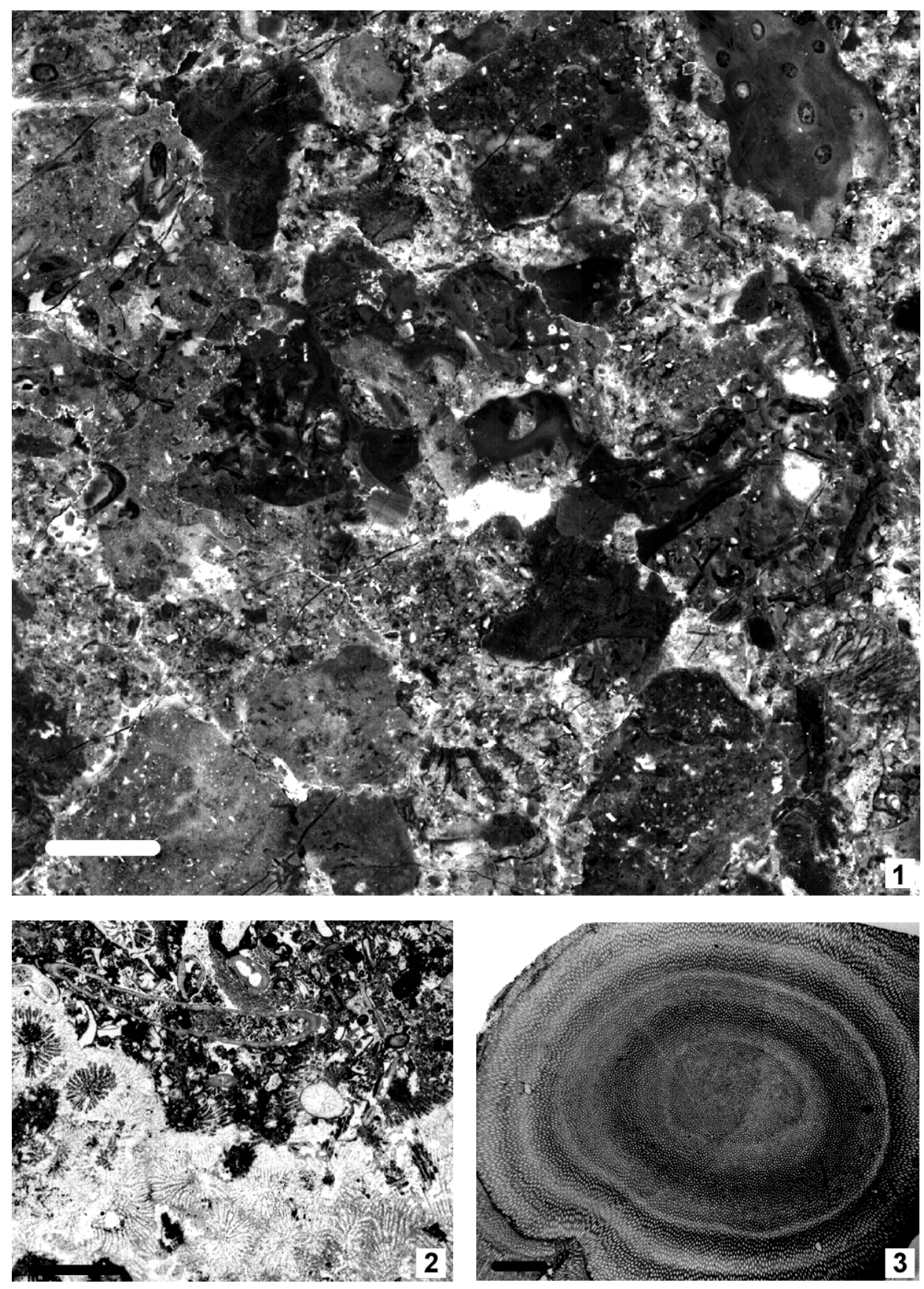
MICROFACIES AND MICROFOSSILS IN THE UPPER JURASSIC LIMESTONES ...

PLATE V
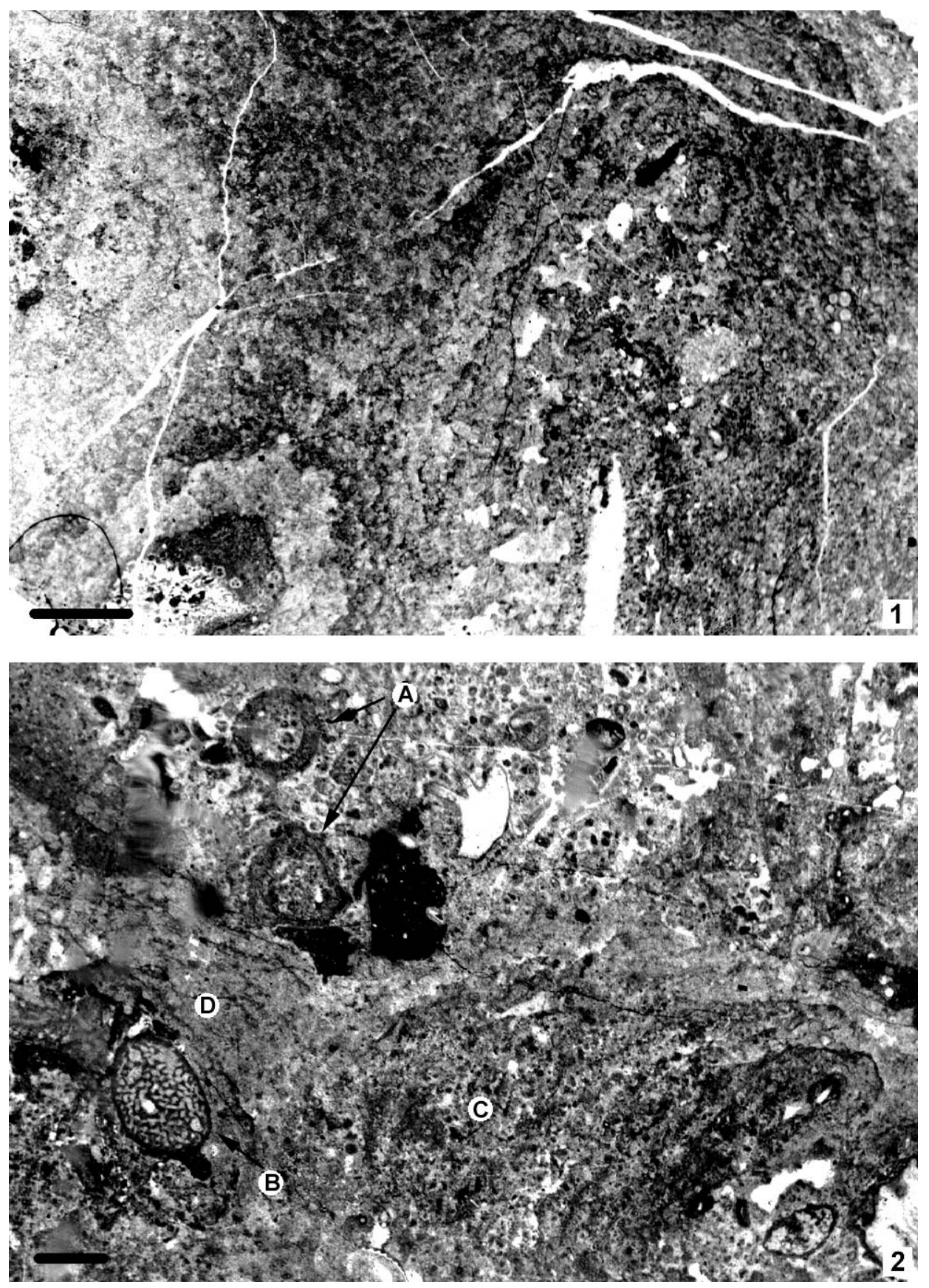
PLATE V
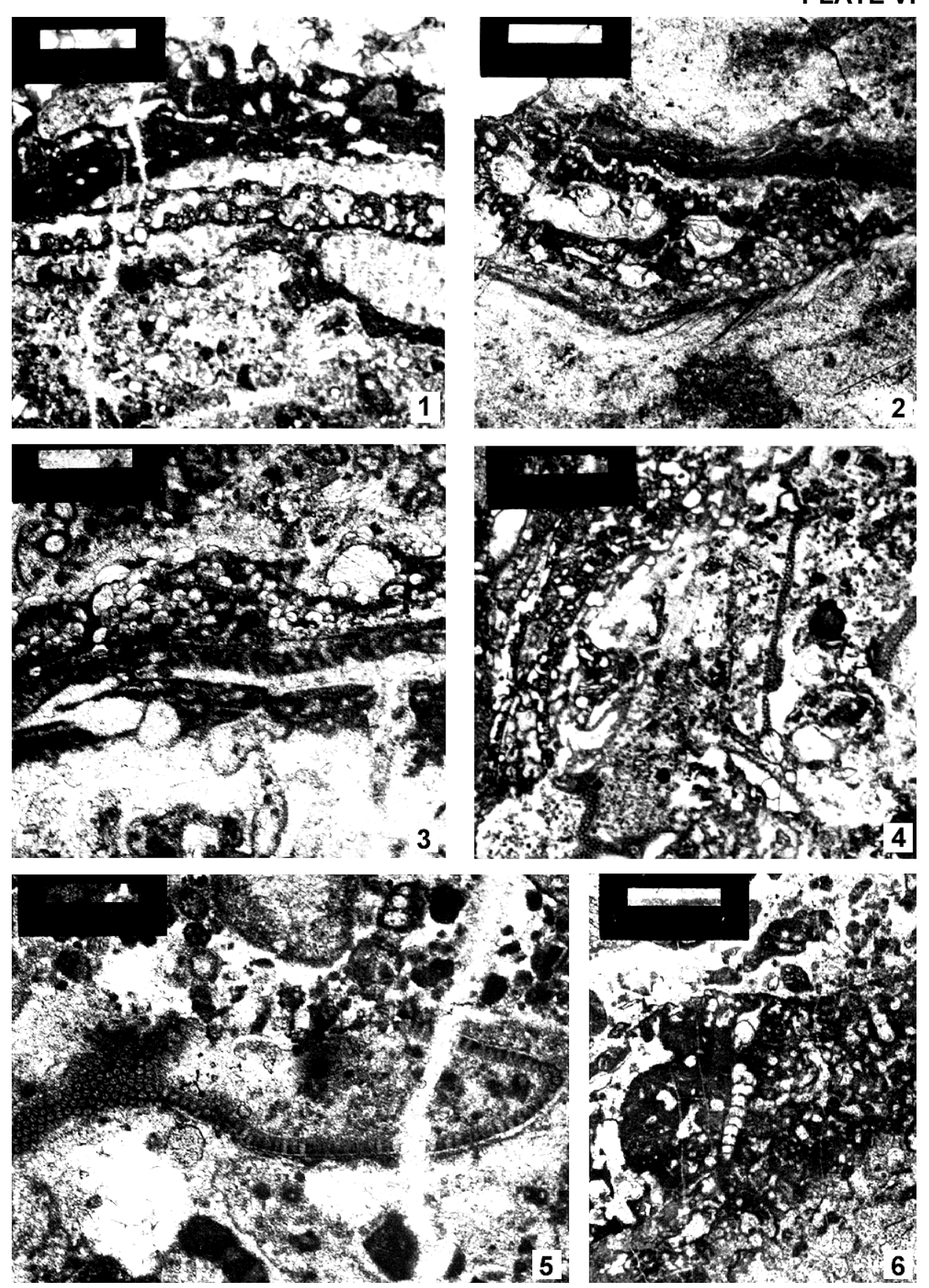

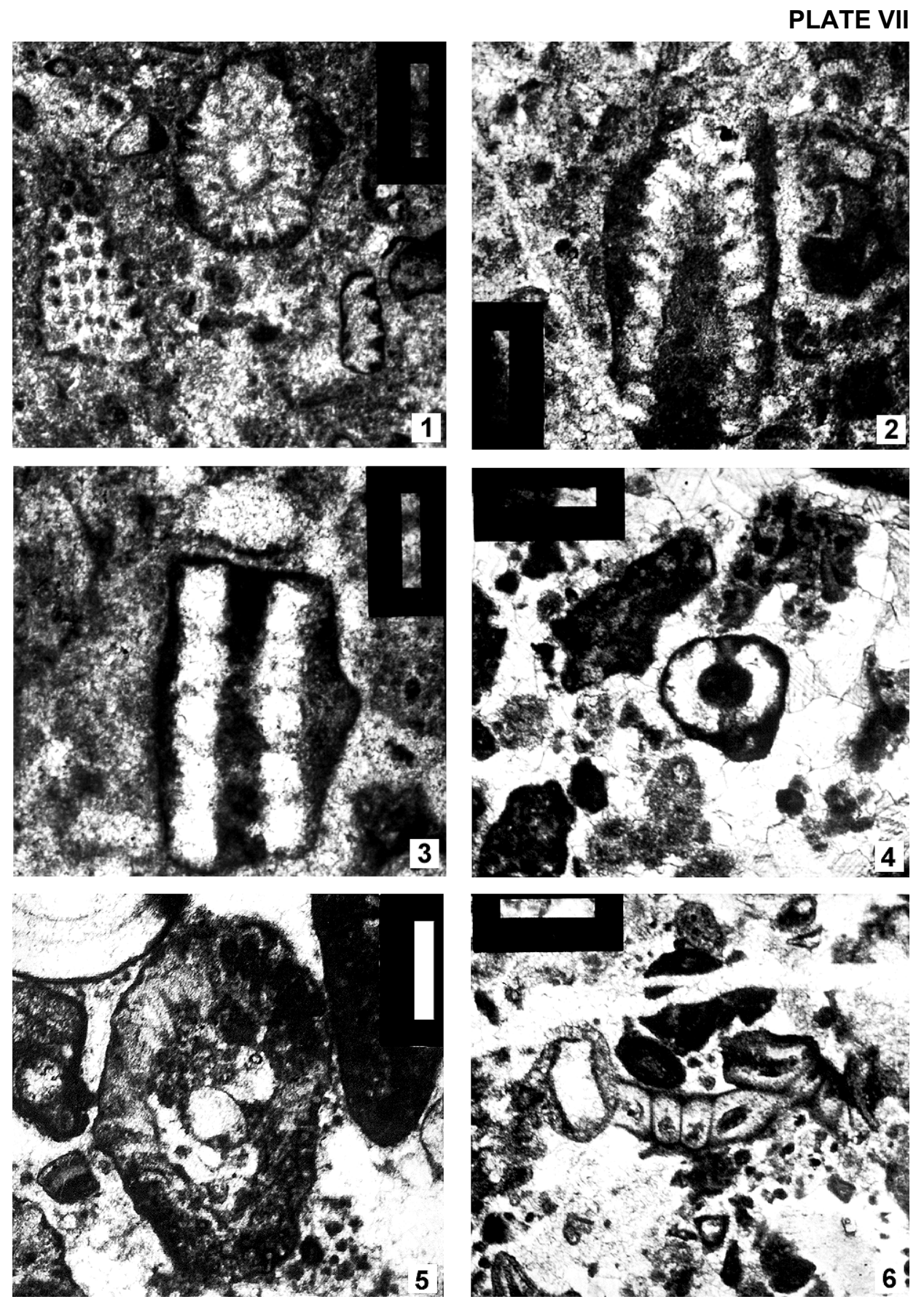
PLATE VIII
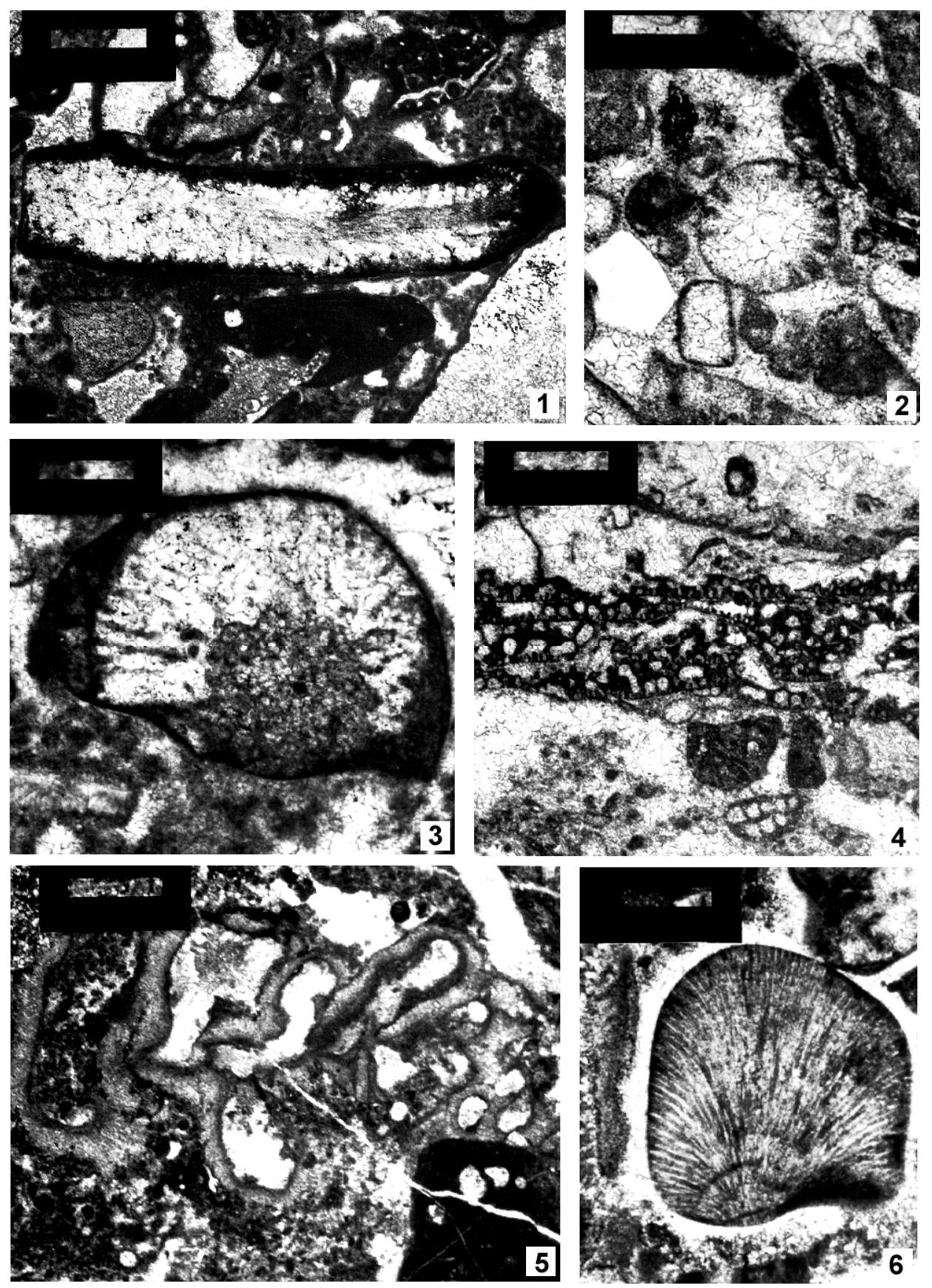


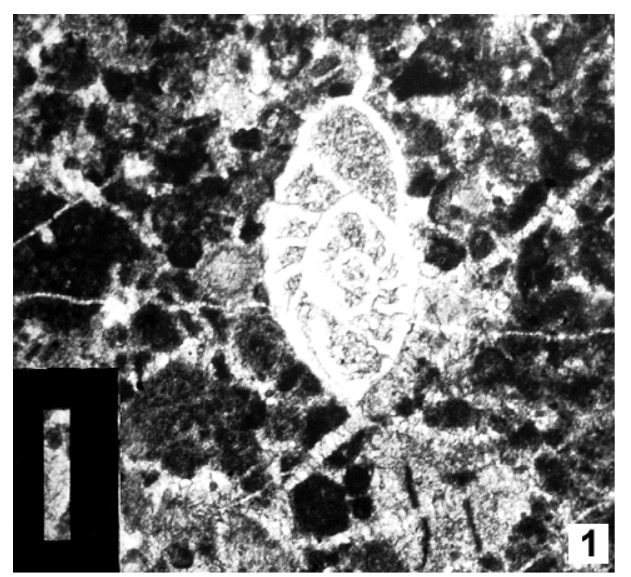

PLATE IX
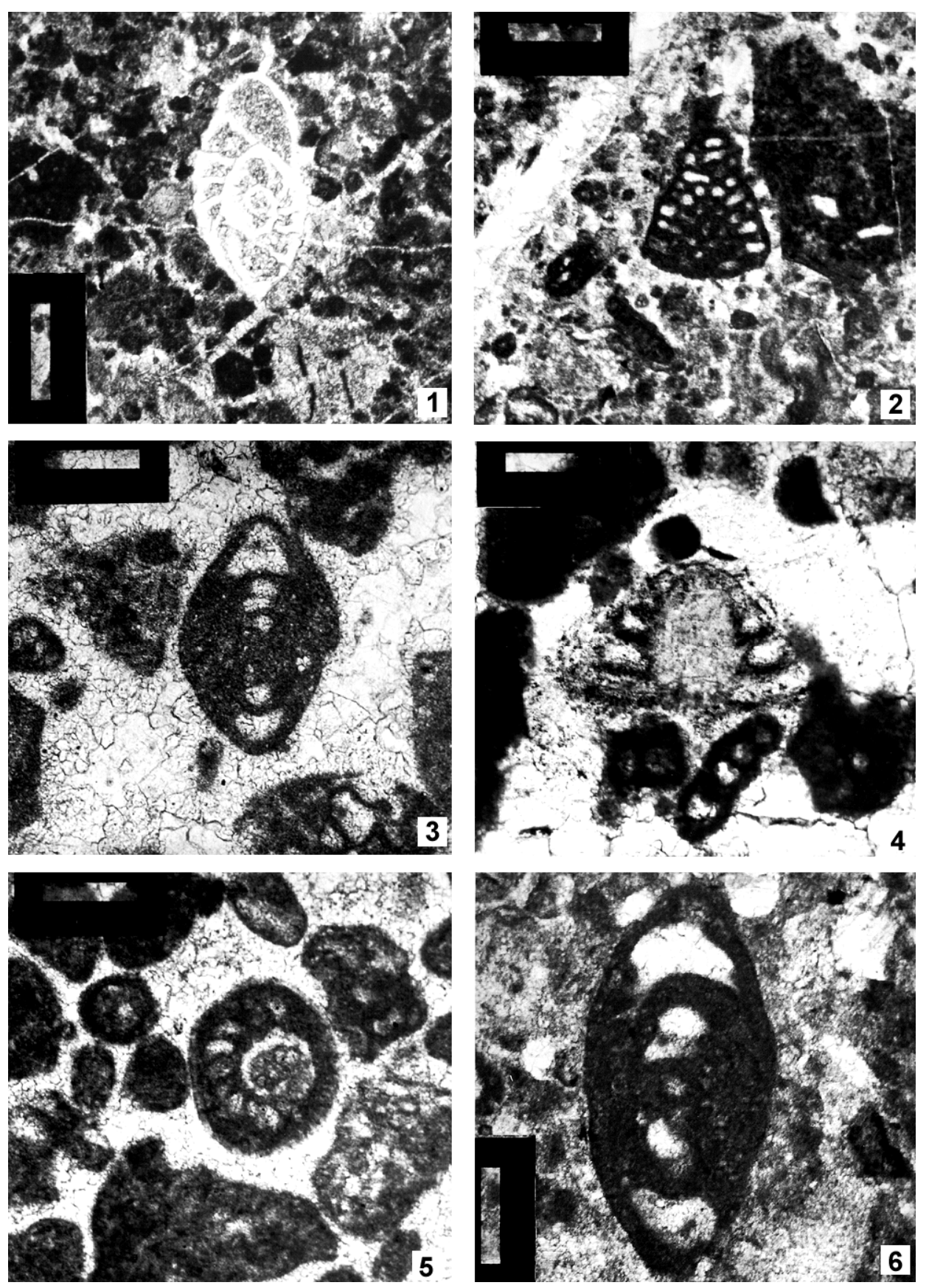
PLATE $X$
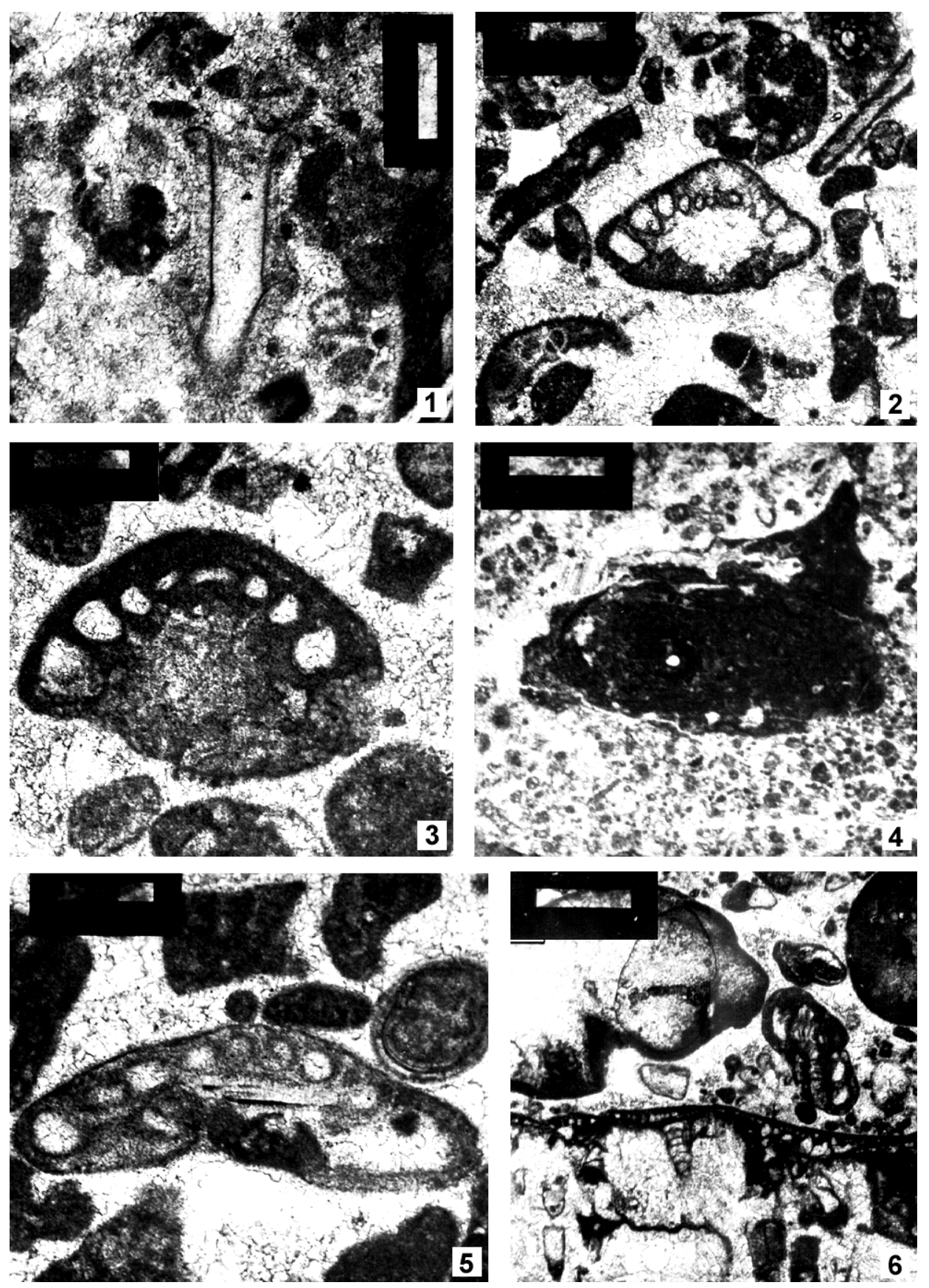